\title{
SCENARIO OF THE DEVELOPMENT OF LIBRARY AND INFORMATION SCIENCE SCHOOLS AND CURRENT RESEARCH TRENDS IN NORTH INDIA
}

\author{
Dr. Joginder Singh \\ Sr. Assistant Librarian, University of Jammu, India
}

\begin{abstract}
This paper traces the histories of the development of LIS schools established in various Universities and institutions before and after independence in India and also traces the scenario of the current trends of research in Library and information science discipline. Library schools must bear the heavier responsibility to deliver high quality education to LIS professionals in India. Library Schools in North India also attracting more and more students but on the other side they moved so far away from teaching LIS education in a form required by their job market. LIS schools needs to form a system of regular contacts with employers and the users of libraries. Employers expectations and users services would inspire LIS schools to develop their manpower, infrastructure, teaching technique, research toward global level and design their LIS course in a more logical and practical manner.
\end{abstract}

Key words: Library and information science education, LIS School, Library Research, Teaching Methods, LIS Curricula and Courses.

Cite this Article: Dr. Joginder Singh, Scenario of the Development of Library and Information Science Schools and Current Research Trends in North India. International Journal of Library \& Information Science, 7(1), 2018, pp. 47-62. http://iaeme.com/Home/issue/IJLIS?Volume=7\&Issue=1

\section{INTRODUCTION}

The development of the profession of Librarian in India established more than hundred years ago. Past history shows that there was little emphasis given on library service in the modern sense. During establishment of librarian profession library training was not essential and an apprenticeship in a library was sufficient. The credit for first training programme librarian in India given to an Englishman John MacFarlane, who happened to be the first librarian of the Imperial Library (now National Library, Kolkota). The Imperial Library was organized training programme during 1901 and 1906 for its staff. Later on it was extended to librarians working in Calcutta. The credit for initiating formal education in librarianship goes to Maharaja Gaekwad of Baroda (1862-1939) during 1911 which is now Vadodra, in Gujarat. 
He was convinced, however, that unless there was adequate follow-up as a life-long process of self-education, a few years of primary education was of little use. He chose the free public library as the agency that must take charge of enlightenment of the masses after their formal education was over. Thus, he linked a free primary school with a free public library as a matter of rule. This concept of free public libraries was carried to India from the USA" (Chakravarty, 1962: 3). Maharaja Gaekwad also visited to developed countries like USA and Europe to acquire firsthand knowledge of their life, culture and society. He was deeply impressed with the public library system developed in USA. He took a creative step in Library education movement in India and invited William Alanson Borden to set up public libraries in the State of Baroda. Borden was an eminent library expert who had been a lecturer at the famous Library School established in 1887 at Columbia. He spent three years for organizing a library system and started the first training course for library professionals at Central Library in Baroda in 1911. He served as Director of State Libraries from 1910 to 1913. During this short period he organized the Library Department and also conducted library training classes to train staff for the Central Library at Baroda and also to man the Library Department for putting through a comprehensive library development programme (Chakravarty, 1962). The credit for establishing a first formal course for imparting librarianship for training in India also goes to W.A. Borden, began in 1911. Another American librarian, Asa Don Dickinson, was appointed by the Indian Government in 1915 at the University of Punjab, Lahore (now in Pakistan) to organize and catalogue its library. As a university librarian he started the university level course for the first time. He introduced a course of training in library methods, which was considered to be the first library school in India and first in Asia, patronized under the University system. The Librarian School founded at Barcelona is the oldest library school in Europe. Konnur opines that Dickenson was probably the first to use the term 'Library Science' for his training course in place of 'Librarianship' (Konnur, 1986). In 1919, University of Punjab awarded a certificate in Modern Library Methods. After the course work, there was practical training of library work for three months. During his one year stay, Dickenson also authored the first ever textbook on library education, entitled "Punjab Library Primer", for introductory as well as better understanding of the library course, which was published by the Punjab University, Lahore in 1916 (Ameen, 2007).

Dr. S.R. Ranganathan invited at University of Delhi to organize a Department of Library Science in 1947. First post-diploma degree course was offered at the University of Delhi in 1948, but later on in 1949 it was changed into Master of Library science course. In India Aligarh Muslim University initiated first Bachelor of Library Science course in 1957. During 1960 Madras University was conducting one year diploma course, it changed to Bachelor of Library Science degree course. There were only three LIS Schools offering Master of Library Science course like University of Delhi, Banaras Hindu University (1965) and University of Bombey (1967). Documentation Research and Training Centre (DRTC) at Banglore was also established by Dr. Ranganathan in 1962. In 1978, the Delhi University also introduced the first M. Phil. course in library science in India. For many years the University of Madras served as a model for the development of library Science education (from 1937 to 1950s). More new departments of library science came into existence between 1956 and 1959 (6), 1960 (19), 1970 (20), and after 1970 (24), respectively (Shrivastava, 2002). At present it is estimated that 120 universities offer a Bachelor's degree, 78 a Master's degree, 21 offer a twoyear integrated Master's degree, 16 offer an M.Phil., and 63 offer a $\mathrm{PhD}$ in Library and Information Science (Sarkhel, 2006).

Today there are nearly 27 universities that conduct the courses via distance education. According to UGC Model Curriculum (2001) there are 14 Certificate courses, 12 
undergraduate Diploma Courses, 68 Bachelors Degree, and 75 Master Degree programme that are being run. The research activity taking place in LIS departments is also commendable, with 63 university departments offering Ph.D. degree programme and 16 MPhil programme. In addition the Documentation Research and Training Centre (DRTC), Bangalore is offering a two-year Associateship in Information Science. Recently, DRTC renamed its course as MSLIS (Varalkshmi, 2009). There are following courses being offered presently in India. Certificate course in Library science; Diploma and Post graduate diploma in Library science; Honors course in Library and information science; BLIS; MLIS one year; 2 year integrated course in MLIS; M.Phil; Ph.D. in Library \& information science; Certificate in ICT application in Library (CICTAL); P.G. Diploma in Library automation and Networking (PGDLAN) (Mahapatra, 2006:3).

\section{OBJECTIVES}

The main objective of this study is to analyze the scenario of the development of Library and Information Science Schools and current research trends in North India. Some of the objectives are as follows:

- To review and analyze the existing situation of growth and development of LIS school in North India.

- To find out the changes taking place in the nomenclature of LIS Schools.

- To identify the availability of the faculty positions and course wise intake of students in the existing department.

- To identify the existing coursed offered by these LIS schools through regular as well as distance mode.

- To explore issues of availability of infrastructure in LIS Schools to fulfill the requirements of the faculties and students.

- To review the teaching techniques and teaching methods used.

- To review and analyze the current research conducting in North Indian LIS School.

\section{METHODOLOGY}

This study included 28 LIS Schools in North India, about 30 Universities/Institutes in North India are conducting 32 LIS programme through regular as well as distance mode (KUK, MDU, IGNOU, RTOU, VMOU and SHIATS universities were conducted LIS courses through distance mode). Thus, the data for this study was collected from respective websites and personally through questionnaires from these LIS Schools from the seven states i.e. J\&K, Himachal Pradesh, Uttrakhand, Punjab, Haryana, Uttar Pradesh and Rajasthan and two Union territories (Delhi and Chandigarh) of Northern India. The survey method was adopted and the questionnaires were designed for comprehensive data collection.

\section{SCOPE AND LIMITATIONS}

The scope of this study is limited to LIS Schools established at North Indian universities and institutions offering LIS education through regular as well distance mode. This study has been discussed the scenario of the development of Library and Information Science Schools in North India. The data was collected from the Library and Information Science Departments of Northern Indian Universities/Institutes of these seven States i.e. Jammu \& Kashmir, Himachal Pradesh, Uttrakhand, Punjab, Haryana, Uttar Pradesh, Rajasthan and Union Territories of Delhi and Chandigarh. 


\section{FINDINGS AND DISCUSSION}

At present 32 LIS courses are conducting LIS courses through regular as well as distance mode in North India. The Table-1 shows the state wise establishment of universities, nomenclature of LIS School, dates of establishment and department attached with different faculties. The University of Delhi was the first university to start Department of Library Science and introduced the courses from the level of Certificate in Library Science to Doctoral degree level course.

Table 1 Department Details

\begin{tabular}{|c|c|c|c|c|}
\hline State & University & Nomenclature of LIS School & $\begin{array}{c}\text { Year of } \\
\text { Establis } \\
\text { hment }\end{array}$ & Attached with Faculty \\
\hline \multirow{2}{*}{$\begin{array}{l}\text { Jammu \& } \\
\text { Kashmir }\end{array}$} & $\mathrm{JU}$ & Library \& Information Science & 1971 & Social Sciences \\
\hline & KU & Library \& Information Science & 1970 & Arts \\
\hline $\begin{array}{l}\text { Himachal } \\
\text { Pradesh }\end{array}$ & HPCU & Library \& Information Science & 2010 & $\begin{array}{l}\text { School of Maths, } \\
\text { Computer \& } \\
\text { Information Science }\end{array}$ \\
\hline Uttrakhand & KUN & Information Science & 2009 & Sciences \\
\hline \multirow{2}{*}{ Haryana } & KUK & Library \& Information Science & 1963 & Arts \& Languages \\
\hline & MDU & Library \& Information Science & 2010 & Social Sciences \\
\hline \multirow[b]{2}{*}{ Punjab } & GNDU & Library \& Information Science & 1973 & Arts \& Social Sciences \\
\hline & PUP & Library \& Information Science & 1969 & $\begin{array}{l}\text { Education \& } \\
\text { Information Science }\end{array}$ \\
\hline Chandigarh UT & PUC & Library \& Information Science & 1960 & Arts \\
\hline \multirow{4}{*}{ Delhi UT } & DU & Library \& Information Science & 1946 & Arts \\
\hline & IGNOU & LIS Programs & 1989 & Social Sciences \\
\hline & JMI & Dr. Zakir Hussain Library & 1985 & Social Sciences \\
\hline & NISCAIR & Education \& Training Divn. & 1952 & Social Sciences \\
\hline \multirow{14}{*}{ Uttar Pradesh } & AMU & Library \& Information Science & 1950 & Social Sciences \\
\hline & BBAU & Library \& Information Science & 2000 & $\begin{array}{l}\text { Information Science \& } \\
\text { Technology }\end{array}$ \\
\hline & BHU & Library \& Information Science & 1941 & Arts \\
\hline & BU & Dr. S.R. Ranganathan Institute of LIS & 1986 & Sciences \\
\hline & CSMU & Library \& Information Science & 2002 & Arts \\
\hline & CCSU & Library \& Information Science & 2004 & Arts \\
\hline & DBRAU & Library \& Information Science & 1984 & Social Sciences \\
\hline & DRMLAU & Library \& Information Science & 2001 & Sciences \\
\hline & GNKV & Library \& Information Science & 1985 & Humanities \\
\hline & LU & Library \& Information Science & 1971 & Arts \\
\hline & RTOU & Library \& Information Science & 1999 & Humanities \\
\hline & RUBC & Library \& Information Science & 2002 & Arts \\
\hline & SHIATS & Library \& Information Science & 2001 & $\begin{array}{l}\text { Humanities \& Social } \\
\text { Science }\end{array}$ \\
\hline & SSV & Library \& Information Science & 1967 & Social Sciences \\
\hline Rajasthan & RU & Library \& Information Science & 1960 & Faculty of Education \\
\hline
\end{tabular}

Note: JU: University of Jammu; KU: University of Kashmir; CUHP: Central University of Himachal Pradesh, Dharamshala; KUN: Kumaun University Nainital; KUK: Kurukshetra University Kurukshetra; MDU: Maharishi Dayanand University, Rohtak; GNDU: Guru Nanak Dev University, Amritsar; PUP: Punjabi University, Patiala; IGNOU: Indira Gandhi National Open University, New Delhi; JMI: Jamia Milia Islamia, New Delhi; NISCAIR: National Institute of Science Communication and Information Resources, New Delhi; AMU: Aligarh Muslim University, Aligarh; BBAU: Babasahib Bhim Rao Ambedkar University, Lucknow; BHU: Banaras Hindu University, Banaras; 
BU: Bundelkhand University, Jhansi; CSMU: Chhatrapati Shahu Ji Maharaj University, Kanpur; CCSU: Choudhary Charan Singh University, Meerut; DBRAU: Dr. Bhim Rao Ambedkar University, Agra; DRMLAU: Dr. Ram Manohar Lohia Awadh University, Faizabad; GNKV:Gandhi National Kashi Vidyapeeth, Varanasi; LU: Lucknow University, Lucknow; RTOU: Rajarshi Tandon Open University, Allahabad; RUBC: M. J. P. Rohilkhand University, Bareilly (Bareilly College, Bareilly; SHIATS: Sam Higginbotom Institute of Agriculture, Technology \& Sciences, Allahabad; SSV: Sampurna Sanskrit Vishwavidyalaya, Varanasi; and RU: University of Rajasthan, Jaipur.

\subsection{Growth of LIS Schools}

The growth of LIS Schools set up per decade in North India indicated in Table-1 shows that the decade wise growth was the same i.e. 3 to 5 LIS schools were set up in the North India per decade. This growth slowed a bit during the 1990/s as only 2 LIS Schools were set up during this period and growth further increased during the decade 2001-10 as a maximum number of 8 LIS Schools were established during this period. Among the LIS Schools most of 13 exist in Uttar Pradesh, with 3 each in Delhi NCR and Rajasthan, 2 each in Punjab and Haryana and one each in Himachal Pradesh, Uttrakhand and Chandigarh Union Territory.

\subsection{Nomenclature}

The nomenclature indicated in Table-1 shows that majority of universities/institutes in North India have adopted "Library and Information" nomenclature to their LIS department and the degree named as BLIS (Bachelor of Library and Information Science or MLIS (Master of Library and Information Science). According to Alimohammadi, (2007) out of a total 75 schools in India, Library and Information Science nomenclature used in 60; Library Science in 8; Information Science in 4; single each in Computer and Information Sciences; Documentation and Information Science; Library Automation and Networking.

\subsection{Department Attached under faculty}

The study shows that the LIS Schools were attached to eleven different faculties in North India. Majority of Universities/institutes have placed their LIS School under the Arts and Social Sciences faculty followed by Sciences, Humanities, the School of Information Science and Technology, Faculty of Education, Faculty of Education and Information Science, Arts and Languages and School of Mathematics, Computer and Information Science respectively.

\subsection{Faculty positions}

Norms for establishing the teacher to students' ratio for various study programs in Universities not strictly followed. Table 2 shows that IGNOU and KUK had the highest number of Professors i.e. 4, followed by PUP, AMU and DU with 2 each, followed by JU, $\mathrm{KU}, \mathrm{HPCU}, \mathrm{MDU}, \mathrm{GNDU}, \mathrm{PUC}, \mathrm{BBAU}, \mathrm{BHU}$ and BU having one each and the remaining 14 having none. AMU and DU had the highest number of associate professors with three, followed by BBAU, BHU, BU, DBRAU and RU having one each, while the remaining 21 LIS schools had none. Further KU had the highest number of assistant professors with 5, followed by DU having 4, followed by KUN, KUK, MDU, PUP, BBAU, BHU and SHIATS having three assistant professors each and JU, HPCU, GNDU, IGNOU, BU, PUC, AMU, GNKV and RU having 2 each and LU having one and the remaining 8 LIS schools having none. The CSMU had the highest number of lecturers with 5, followed by RUBC having 3 , GNKV having 2. The DRMLAU, RTOU and RUBC had one Librarian teaching at an LIS school while JMI and CCSU had the highest number of Deputy Librarians 3, followed by JMI with 3 assistant librarians. Further the senior Principal Scientist, Principle Scientist, technical officer have one each, BU and CCSU had 3 teaching assistants. DRMLAU and LU had the 
highest number of guest faculty at 4, followed by CCSU, DBRAU and SSV with 2 each, and the remaining being only guest faculty.

Table 2 Faculty Positions

\begin{tabular}{|c|c|c|c|c|c|c|c|c|c|c|c|c|c|}
\hline University/Institute & 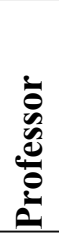 & 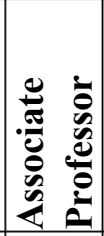 & 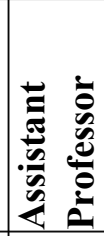 & & 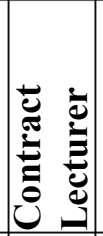 & 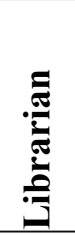 & 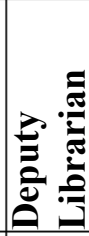 & 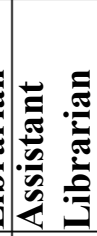 & 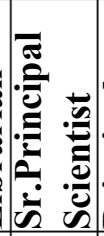 & 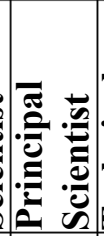 & 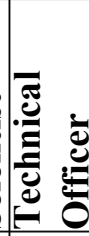 & 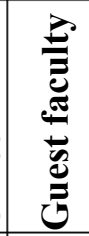 & 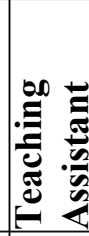 \\
\hline \multicolumn{14}{|l|}{ Jammu \& Kashmir } \\
\hline $\mathrm{JU}$ & 1 & & 2 & & 2 & & & & & & & & \\
\hline KU & 1 & & 5 & & & & & & & & & & \\
\hline \multicolumn{14}{|l|}{ Himachal Pradesh } \\
\hline HPCU & 1 & & 2 & & & & & & & & & & \\
\hline \multicolumn{14}{|l|}{ Uttrakhand } \\
\hline KUN & & & 3 & & & & 1 & & & & & & \\
\hline \multicolumn{14}{|l|}{ Haryana } \\
\hline KUK & 4 & & 2 & & & & & & & & & & \\
\hline MDU & 1 & 1 & 3 & & & & & & & & & & \\
\hline \multicolumn{14}{|l|}{ Punjab } \\
\hline GNDU & 1 & & 2 & & & & & & & & & & \\
\hline PUP & 2 & 1 & 3 & & & & & & & & & & \\
\hline \multicolumn{14}{|l|}{ Chandigarh UT } \\
\hline PUC & 1 & 1 & 2 & & & & & & & & & & \\
\hline \multicolumn{14}{|l|}{ Delhi UT } \\
\hline DU & 2 & 3 & 4 & & & & & & & & & & \\
\hline IGNOU & 3 & & 2 & & & & & & & & & & \\
\hline JMI & & & 1 & & & & 2 & 1 & & & & & \\
\hline NISCAIR & & & & & & & & & 1 & 1 & 1 & & \\
\hline \multicolumn{14}{|l|}{ Uttar Pradesh } \\
\hline AMU & 2 & 3 & 2 & & 2 & & & & & & & & \\
\hline BBAU & 1 & 1 & 3 & & & & & & & & & & \\
\hline $\mathrm{BHU}$ & 1 & 1 & 3 & & & & & & & & & & \\
\hline $\mathrm{BU}$ & 1 & 1 & 2 & & & & & & & & & & 2 \\
\hline CSMU & & & & 5 & & & & & & & & & \\
\hline CCSU & & & & 1 & & & 1 & & & & & 2 & 1 \\
\hline DBRAU & & 1 & & & 1 & & & & & & & 2 & \\
\hline DRMLAU & & & & & & 1 & & & & & & 4 & \\
\hline GNKV & & & 2 & 2 & & & & & & & & & \\
\hline $\mathrm{LU}$ & & & 1 & & & & & & & & & 4 & \\
\hline RTOU & & & & 1 & & 1 & & 1 & & & & & \\
\hline RUBC & & & & 3 & & 1 & & & & & & & \\
\hline SHIATS & & & 3 & & & & & & & & & & \\
\hline SSV & & & & & & & & 1 & & & & 2 & \\
\hline \multicolumn{14}{|l|}{ Rajasthan } \\
\hline RU & & 1 & 2 & & & & & & & & & & \\
\hline Total & 22 & 14 & 49 & 12 & 5 & 3 & 4 & 3 & 1 & 1 & 1 & 14 & 3 \\
\hline
\end{tabular}

\subsection{Courses Offered}

In $21^{\text {st }}$ century LIS education underwent enormous changes due to technological changes. The Development of Technology has made substantial impact on LIS education and its nomenclature. The LIS courses were initiated earlier as Certificate and diploma courses in LIS education. Later on its nomenclature was changed to Bachelor of Library Science and Master of Library Science. The change has been effected the nomenclature of LIS courses and its course contents being offered and presently most of the universities adopted the course 
name 'Bachelor of Library and Information Science' and 'Master of Library and Information Science'. Some of Indian Universities are offering LIS courses on different levels such as Certificate courses, Diploma courses, PGDLAN, BLIS, MLIS, MLIS (2 years Integrated course) M. Phil, Ph. D, D.Lit. programs and other different courses offered by the university like Calcutta University offering LIS four years integrated degree course on regular basis and Banaras Hindu University offering two years Integrated course MA in Manuscriptology and Paleography. The Table -3 shows the LIS courses offered by LIS schools in northern Indian universities, their year of course initiation and present intake of students. Out of the total universities studied 17 had more than 30 seats for the BLIS course while the remaining had less than 20 seats. Only six universities/institutes have more than 30 seats for the MLIS course while six universities offered more than 10 seats in Ph.D. The remaining universities had less than 10 seats.

Table 3 Courses, Year of Starting and Present Intake

\begin{tabular}{|c|c|c|c|c|c|c|c|c|c|c|c|}
\hline \multirow[b]{2}{*}{$\begin{array}{c}\text { Universit } \\
y\end{array}$} & \multicolumn{2}{|c|}{ BLIS } & \multicolumn{2}{|c|}{ MLISC } & \multicolumn{2}{|c|}{ M. Phil } & \multicolumn{2}{|c|}{ Ph. D } & \multicolumn{2}{|c|}{$\begin{array}{c}\text { MLISC } \\
\text { (Integrated) }\end{array}$} & \multirow{2}{*}{ 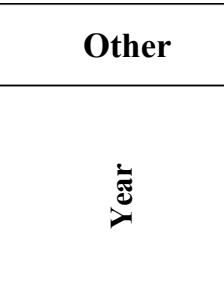 } \\
\hline & 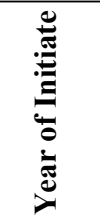 & 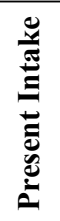 & 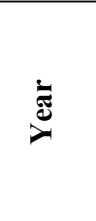 & 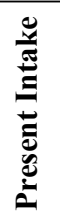 & 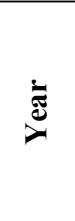 & 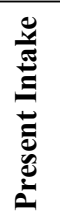 & $\stackrel{\bar{\varpi}}{\nu}$ & 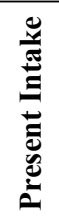 & $\stackrel{\bar{\varpi}}{\nu}$ & 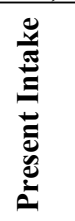 & \\
\hline \multicolumn{12}{|l|}{$\begin{array}{l}\text { Jammu and } \\
\text { Kashmir }\end{array}$} \\
\hline JU & 1983 & 30 & 1985 & 15 & & & 1985 & 10 & & & \\
\hline KU & & & 1984 & & $\begin{array}{c}198 \\
5\end{array}$ & 5 & 1985 & 10 & & 42 & \\
\hline \multicolumn{12}{|l|}{$\begin{array}{l}\text { Himachal } \\
\text { Pradesh }\end{array}$} \\
\hline CUHP & & & & & & & & & 2010 & 30 & \\
\hline \multicolumn{12}{|l|}{ Uttrakhand } \\
\hline KUN & 2009 & 34 & 2010 & 16 & & & & & & & \\
\hline \multicolumn{12}{|l|}{ Haryana } \\
\hline KUK & 1963 & 40 & 1986 & 40 & $\begin{array}{c}200 \\
6\end{array}$ & 10 & & 20 & & & \\
\hline MDU & 2010 & 23 & 2010 & 23 & & & & & & & \\
\hline \multicolumn{12}{|l|}{ Punjab } \\
\hline GNDU & 1973 & 30 & 1985 & 20 & & & 1985 & 2 & & & \\
\hline PUP & 1969 & 33 & 1987 & 21 & & & & 13 & & & \\
\hline \multicolumn{12}{|c|}{\begin{tabular}{l|l} 
Chandigarh & \\
UT &
\end{tabular}} \\
\hline PUC & 1968 & & 1970 & & & & 1988 & 11 & & 45 & \\
\hline \multicolumn{12}{|l|}{ Delhi } \\
\hline DU & & 60 & 1949 & 46 & $\begin{array}{c}197 \\
0\end{array}$ & 10 & 1950 & 24 & & & \\
\hline IGNOU & 1989 & & 1994 & & & & 2001 & 6 & & & $\begin{array}{c}\text { CICTAL, } \\
\text { PGDLAN } \\
(2008)\end{array}$ \\
\hline JMI & 1958 & 35 & & & & & & & & & \\
\hline \multicolumn{12}{|l|}{$\begin{array}{l}\text { Uttar } \\
\text { Pradesh }\end{array}$} \\
\hline AMU & 1959 & 60 & 1971 & 25 & & & 1990 & 4 & & & \\
\hline BBAU & & & & & & & 2000 & 7 & 1997 & 30 & \\
\hline BHU & & & & & & & & 24 & & 46 & $\begin{array}{l}\text { MA } \\
\text { (Manuscriptolo }\end{array}$ \\
\hline
\end{tabular}




\begin{tabular}{|c|c|c|c|c|c|c|c|c|c|}
\hline & & & & & & & & & $\begin{array}{l}\text { gy \& } \\
\text { Paleography) }\end{array}$ \\
\hline $\mathrm{BU}$ & 1986 & 53 & 1992 & 49 & $\begin{array}{c}200 \\
6\end{array}$ & 24 & 2000 & 7 & \\
\hline CSMU & 2002 & 60 & 2003 & 25 & & & & & \\
\hline CCSU & 2004 & 50 & 2004 & 30 & & & & & \\
\hline DBRAU & 1984 & 30 & 1986 & 30 & & & 1998 & 4 & \\
\hline DRMLAU & 2002 & 23 & 2003 & 29 & & & & & \\
\hline GNKV & 1985 & 40 & 2007 & & & & & & \\
\hline LU & 1971 & 40 & 1993 & 20 & & & 1995 & 3 & \\
\hline RTOU & 1999 & $\begin{array}{c}2,00 \\
0\end{array}$ & 2001 & $\begin{array}{c}1,00 \\
0\end{array}$ & $\begin{array}{c}200 \\
9\end{array}$ & 15 & 2005 & 15 & \\
\hline RUBC & 2002 & 40 & & & & & & & \\
\hline SHIATS & 2001 & 10 & 2002 & 23 & & & & & \\
\hline SSV & 1967 & 19 & & & & & & & \\
\hline Rajasthan & & & & & & & & & \\
\hline RU & 1961 & 80 & 1974 & 20 & & & 1975 & 26 & \\
\hline
\end{tabular}

Result shows that most of the LIS schools have more than 30 seats in BLIS and MLIS courses and five universities, namely BBAU, BHU, HPCU, KU and PUC were offering M Phil namely KU, KUK, DU, BU and RTOU respectively and 14 universities are offering Ph.D courses namely JU, BU, IGNOU, GNDU, DU, BBAU, AMU, DBRAU, RU, RTOU, PUC, LU, KUK and KU respectively.

\subsection{Distance Mode LIS Courses}

Distance education was initiated during the decade of 1960s and Andhra Pradesh Open University (Presently Dr. B.R. Ambedkar Open University) established at Hyderabad was the first open university in India. Later on Indira Gandhi National Open University and Annamalai University started offering some of LIS courses through distance mode. In North India six universities namely Indira Gandhi National Open University (IGNOU) New Delhi, Kurukshetra University Kurukshetra (KUK), Maharishi Dayanand University (MDU) Rohatak, Rajarshi Tandon Open University (RTOU) Allahabad, Sam Higginbotom Institute of Agriculture, Technology \& Sciences, Allahabad and Vardhaman Mahavir Open University (VMOU) are conducting the LIS course through distance mode, most of them are offering BLIS and MLIS. Out of these six universities three of them (IGNOU, RTOU AND VMOU) are offering $\mathrm{Ph}$. D. through distance mode.

\subsection{Infrastructures}

The LIS Schools in Northern Indian universities/institutes have not adequate infrastructure facilities to modernize LIS Schools up to the International standards. Western countries such as USA and UK are developing their LIS Schools and manpower to compete with emerging digital era. The infrastructure disparities originated in our LIS Schools due to some political and economic imbalances. The South Indian LIS schools have developed better than their infrastructures facilities compare with Northern Indian LIS Schools and they can be competitive or comparable to western countries. But in case of Northern Indian LIS Schools have lack of ICT policies and support at National level, Lack of adequate computer hardware and software licenses to make accessible to employer and students. The LIS curriculum can be designed on International standard but it can't serve the purpose and there should be adequate infrastructure for offering qualitative teaching. Some of the infrastructure facilities are given below: 
Scenario of the Development of Library and Information Science Schools and Current Research Trends in North India

Table-5 Physical facilities

\begin{tabular}{|c|c|c|c|c|c|c|}
\hline University &  & 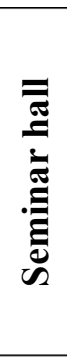 & 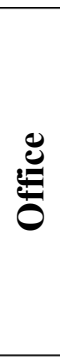 & 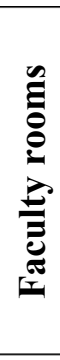 & 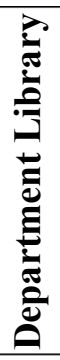 & 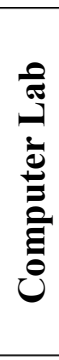 \\
\hline \multicolumn{7}{|l|}{$\begin{array}{l}\text { Jammu and } \\
\text { Kashmir }\end{array}$} \\
\hline $\mathrm{JU}$ & 3 & 1 & 1 & 5 & 1 & 1 \\
\hline KU & 2 & 1 & 1 & 8 & 1 & 1 \\
\hline \multicolumn{7}{|l|}{ Himachal Pradesh } \\
\hline HPCU & 2 & 1 & 1 & 1 & 1 & \\
\hline \multicolumn{7}{|l|}{ Uttrakhand } \\
\hline KUN & 2 & & 1 & 1 & & \\
\hline \multicolumn{7}{|l|}{ Haryana } \\
\hline KUK & 3 & & 1 & 4 & & 1 \\
\hline MDU & 2 & & 1 & 3 & 1 & 1 \\
\hline \multicolumn{7}{|l|}{ Punjab } \\
\hline GNDU & 1 & & 1 & & 1 & \\
\hline PUP & 2 & & 2 & 3 & 1 & 1 \\
\hline \multicolumn{7}{|l|}{ Chandigarh UT } \\
\hline PUC & 2 & & 2 & 5 & 1 & 1 \\
\hline \multicolumn{7}{|l|}{ Delhi UT } \\
\hline DU & 4 & 1 & 2 & 8 & 1 & \\
\hline IGNOU & - & & 1 & 8 & - & \\
\hline JMI & 1 & 1 & 1 & 1 & 1 & 1 \\
\hline NISCAIR & 3 & 1 & 1 & 1 & 1 & 1 \\
\hline \multicolumn{7}{|l|}{ Uttar Pradesh } \\
\hline AMU & 2 & 1 & 1 & 7 & 1 & 1 \\
\hline BBAU & 2 & & 1 & 5 & 1 & 1 \\
\hline BHU & 4 & 1 & 1 & 5 & 1 & \\
\hline $\mathrm{BU}$ & 3 & 1 & 1 & 10 & 1 & \\
\hline CSMU & 3 & & 1 & 1 & & 1 \\
\hline CCSU & 2 & & 1 & 2 & 1 & \\
\hline DBRAU & 2 & 1 & 1 & 2 & 1 & 1 \\
\hline DRMLAU & 2 & 1 & 1 & 2 & & 1 \\
\hline GNKV & 1 & & 1 & & & \\
\hline LU & 2 & & 1 & 3 & 1 & 1 \\
\hline RTOU & 1 & & 1 & 1 & & 1 \\
\hline RUBC & 1 & 1 & 1 & 1 & 1 & 1 \\
\hline SHIATS & 4 & 1 & 1 & 3 & 1 & 1 \\
\hline SSV & 1 & 2 & 1 & 1 & & \\
\hline \multicolumn{7}{|l|}{ Rajasthan } \\
\hline RU & 2 & & 1 & - & 1 & 1 \\
\hline Total & 55 & 15 & 24 & 81 & 1 & 18 \\
\hline
\end{tabular}

Physical facilities presented in Table-5 shows availability of classrooms, seminar hall, department office, faculty rooms, departmental library and computer lab are the basic requirements of any established department. The Table 5 comprehensively indicates that three LIS Schools (at DU, BHU, SHIATS) have four classrooms each, five LIS Schools (at JU, KUK, NISCAIR, BU, CSMU) have three classrooms, 13 LIS Schools (HPCU, KUN, MDU, PUP, PUC, AMU, BBAU, CCSU, DBRAU, DRMLAU, LU and RU) have two classrooms 
and six universities (GNDU, JMI, GNKV, RTOU, RUBC, SSV) have one classroom. Out of 28 LIS schools 18 were satisfied with the available classroom facilities but 10 were not with the facilities provided to them. Most of LIS have office room facilities to serve official purposes. Thus 15 LIS schools were satisfied with the availability of office room facilities. Regarding department office facilities three LIS Schools (at PUP, PUC, DU) have two office rooms in the department, whilethe remaining had a single office room. Regarding faculty rooms one LIS School (BU) have 10 faculty rooms, while three LIS Schools (KU, DU, IGNOU) have eight faculty rooms, one (AMU) have seven faculty rooms, four LIS Schools (JU, PUC, BBAU, BHU) have five faculty rooms, one (KUK) have 4 faculty rooms, six (MDU, GNDU, PUP, LU, SHIATS and RU) have three faculty rooms and three LIS Schools (CCSU, DBRAU, DRMLAU) have two faculty rooms, and two have one faculty room. Thus, 14 LIS schools were satisfied with the availability of faculty rooms, and an equal number were dissatisfied. Out of 28 LIS Schools 20 have departmental library facilities whereas 8 LIS Schools have no department library facility available. Thirteen LIS schools were satisfied with their departmental library facilities, while 15 were not satisfied. On the criterion of availability of Computer Lab, 18 LIS schools have the Computer Lab facility but 10 did not. Thus 10 LIS schools were satisfied with the Computer lab facilities available in their departments.

\subsection{Teaching Equipments}

The adequate infrastructural facilities are one of the significant elements for offering qualitative education and teaching. Teaching equipment holds a unique importance to create teaching and learning interest among teachers and students. It is important to constantly upgrade with latest equipments for effective teaching. Use of Over Head Projectors (OHP), Slide projector, Television and VCR and Smart Class rooms are commonly available for teaching at LIS Schools.

Table 6 Availability of Teaching Equipment

\begin{tabular}{|c|c|c|c|c|c|}
\hline University & OHP & $\begin{array}{c}\text { Slide } \\
\text { Projector }\end{array}$ & $\begin{array}{c}\text { Television \& } \\
\text { VCR }\end{array}$ & LCD & $\begin{array}{c}\text { Smart Class } \\
\text { Rooms }\end{array}$ \\
\hline \multicolumn{6}{|l|}{$\begin{array}{l}\text { Jammu and } \\
\text { Kashmir }\end{array}$} \\
\hline $\mathrm{JU}$ & & & & 1 & \\
\hline KU & 1 & 1 & & & \\
\hline \multicolumn{6}{|l|}{$\begin{array}{l}\text { Himachal } \\
\text { Pradesh }\end{array}$} \\
\hline HPCU & & & & 1 & 1 \\
\hline \multicolumn{6}{|l|}{ Uttrakhand } \\
\hline \multicolumn{6}{|l|}{ KUN } \\
\hline \multicolumn{6}{|l|}{ Haryana } \\
\hline KUK & 1 & & & 1 & \\
\hline MDU & & & & 2 & 2 \\
\hline \multicolumn{6}{|l|}{ Punjab } \\
\hline GNDU & 1 & 1 & 1 & 1 & \\
\hline \multicolumn{6}{|l|}{ PUP } \\
\hline \multicolumn{6}{|l|}{ Chandigarh UT } \\
\hline PUC & 1 & 1 & & 1 & \\
\hline \multicolumn{6}{|l|}{ Delhi UT } \\
\hline DU & 2 & 1 & & 2 & \\
\hline \multicolumn{6}{|l|}{ IGNOU } \\
\hline JMI & 1 & & & & \\
\hline NISCAIR & 2 & 3 & 1 & 2 & \\
\hline Uttar Pradesh & & & & & \\
\hline
\end{tabular}


Scenario of the Development of Library and Information Science Schools and Current Research Trends in North India

\begin{tabular}{|c|c|c|c|c|c|}
\hline AMU & 1 & & 1 & 1 & 1 \\
\hline BBAU & 1 & & & & \\
\hline BHU & 1 & 3 & 1 & 3 & \\
\hline BU & & & & 1 & \\
\hline \multicolumn{6}{|l|}{ CSMU } \\
\hline CCSU & 2 & 2 & & 1 & 1 \\
\hline DBRAU & 1 & 1 & & 1 & \\
\hline DRMLAU & 1 & & & & \\
\hline \multicolumn{6}{|l|}{ GNKV } \\
\hline $\mathrm{LU}$ & 1 & 1 & & & \\
\hline RTOU & & 1 & & 1 & \\
\hline \multicolumn{6}{|l|}{ RUBC } \\
\hline SHIATS & 1 & 1 & & 1 & 1 \\
\hline \multicolumn{6}{|l|}{ SSV } \\
\hline \multicolumn{6}{|l|}{ Rajasthan } \\
\hline RU & 2 & 1 & & 1 & \\
\hline Total & 20 & 17 & 4 & 21 & 6 \\
\hline$\%$ Age & 71.4 & 60.7 & 14.3 & 75 & 21.4 \\
\hline
\end{tabular}

Result in Table 6 shows that 12 LIS Schools had an OHP each and 4 universities (DU, NISCAIR, CCSU, RU) equally have two OHP, whereas 12 universities have none. Regarding Slide Projectors 9 LIS Schools have a single slide projector, while 2 LIS Schools (NISCAIR, BHU) have 3 slide projectors each. One LIS School has only a single projector, while the remaining 16 did not have any slide projector. All these equipments availability was inquired actual use may differ. Regarding the availability of Televisions and VCRs 4 LIS Schools have a Television and a VCR but 24 LIS Schools have no television or VCR. Regarding LCD's, 12 LIS Schools have a single LCD, whereas 3 LIS Schools have two LCDs, while one LIS School have three LCD. Remaining 16 have no LCDs. Regarding Smart Class Boards four LIS Schools have a single Smart Class rooms while 24 have no Smart Class.

\subsection{Teaching Methods}

The principles and methods used for instruction can be called a teaching method. Teachers need to use different teaching methods to effectively towards all students. The different types of teaching strategies can be adopted. Students knowledge can be evaluated and selection of suitable strategies for the students. These strategies can be helpful to decide best suitable methods of teaching for particular students or class. The employers responded about the level of their satisfaction with regard to teaching methods and suggested new effective teaching methods in the period of new developments taking place in the information environment. The teachers had to bring more practical perspectives into the classroom. They suggested enhancing the existing instructions with new methods. Table 7 shows that the Lecture and Blackboard method had $28.6 \%$ of the takers finding it Satisfactory, Good and Very Good respectively and $14.3 \%$ finding it to be Excellent. Classroom Seminars were preferred by $42.9 \%$ Heads, while $35.7 \%$ felt they were good, $17.7 \%$ felt them to be Very Good, $14.3 \%$ found them Excellent and 7.1\% found them to be Satisfactory. $57.1 \%$ of the Heads/Chairmen found Dictation or Note giving Satisfactory, 28.5\% found Very Good, and $14.3 \%$ felt it was good. The Lecture and Discussion method of teaching had 35.7\% takers Good had 32.1\% feeling Very Good, 25\% feeling excellent and 7.1\% feeling satisfactory. The Classroom Workshop method of teaching had $46.4 \%$ feeling Good, $28.6 \%$ feeling very Good, $17.9 \%$ feeling Excellent and $7.1 \%$ feeling Satisfactory. The Project/Assignment method of teaching had $42.9 \%$ feeling very good, $25 \%$ feeling good, and $14.3 \%$ feeling Satisfactory and Excellent each. Visits to Library method had $42.9 \%$ feeling Very Good, $28.6 \%$ feeling excellent and 14.3 feeling satisfied and Good each. The Internship method had 46.4\% employers feeling 
Very Good, $28.6 \%$ feeling excellent, $14.3 \%$ feeling good and $10.7 \%$ feeling satisfactory. The Hands-on-training in the Computer Lab was found to be good by $35.7 \%$ with $25 \%$ feeling good and $3.6 \%$ feeling satisfied. Use of AV method was popular among $35.7 \%$ Heads and $28.6 \%$ were feeling good and very good each while $7.1 \%$ were finding it satisfactory.

Table 7 Effectiveness of Teaching Methods

\begin{tabular}{|l|c|c|c|c|c|c|c|c|c|c|}
\hline \multirow{2}{*}{\multicolumn{1}{|c|}{ Method }} & \multicolumn{2}{|c|}{ Satisfactory } & \multicolumn{2}{|c|}{ Good } & \multicolumn{2}{|c|}{ Very Good } & \multicolumn{2}{c|}{ Excellent } & \multicolumn{2}{|c|}{ Total } \\
\cline { 2 - 12 } & $\mathbf{N}$ & $\mathbf{\%}$ & $\mathbf{N}$ & $\mathbf{\%}$ & $\mathbf{N}$ & $\mathbf{\%}$ & $\mathbf{N}$ & $\mathbf{\%}$ & $\mathbf{N}$ & $\%$ \\
\hline Lecture \& Blackboard & 8 & 28.6 & 8 & 28.6 & 8 & 28.6 & 4 & 14.3 & 28 & 100 \\
\hline Lecture \& Discussion & 2 & 7.1 & 10 & 35.7 & 9 & 32.1 & 7 & 25.0 & 28 & 100 \\
\hline Classroom seminar & 2 & 7.1 & 12 & 42.9 & 10 & 35.7 & 4 & 14.3 & 28 & 100 \\
\hline Classroom workshops & 2 & 7.1 & 13 & 46.4 & 8 & 28.6 & 5 & 17.9 & 28 & 100 \\
\hline $\begin{array}{l}\text { Hands on Training in } \\
\text { Computer lab }\end{array}$ & 1 & 3.6 & 7 & 25.0 & 10 & 35.7 & 10 & 35.7 & 28 & 100 \\
\hline Project/Assignment & 4 & 14.3 & 7 & 25.0 & 12 & 42.9 & 4 & 14.3 & 28 & 100 \\
\hline Use of AV Methods & 2 & 7.1 & 8 & 28.6 & 8 & 28.6 & 10 & 35.7 & 28 & 100 \\
\hline Dictation of Note Giving & 16 & 57.1 & 4 & 14.3 & 8 & 28.6 & 0 & 0.0 & 28 & 100 \\
\hline Visits to Library & 4 & 14.3 & 4 & 14.3 & 12 & 42.9 & 8 & 28.6 & 28 & 100 \\
\hline Internship & 3 & 10.7 & 4 & 14.3 & 13 & 46.4 & 8 & 28.6 & 28 & 100 \\
\hline
\end{tabular}

Thus, the analysis reveals that the dictation or note giving methods was still the most satisfactory method of teaching as $57.1 \%$ found it to be Satisfactory, followed by 'Internship and Class Room workshop Method' which had 46.4\% Heads of LIS School finding it to be Very Good and Good, followed by the methods of Class Room Seminar, Project Assignment and Visit to the Library being favored by $42.9 \%$ who found it to be Good and Very Good, followed by Lecturers and discussions, Hands on training in computer lab and use of AV method finding favor with $35.7 \%$ who felt it to be Good, Very good and Excellent respectively.

\subsection{Current Research in LIS School}

Research is a part of the university programme and therefore it was essential to collect data about the research programs being conducted in the universities selected for the study. The research programs/degree offered by the universities are $\mathrm{M}$. Phil and $\mathrm{Ph}$. D. In North India the subject areas on which $\mathrm{Ph} . \mathrm{D}$ research work is presently going on are presented and analyzed in Table 8 reveals that 'user behavior' is the most sought topic chosen by $9.9 \%$ researchers. 'Web based resources' was chosen by 5.6\%, 'Information literacy', 'Digital libraries' were chosen by $4.9 \%$ each, while 'Library Services' chosen by $4.2 \%$, 'Cost effectiveness and Cost Benefit Analysis' and 'Electronic resources' chosen by 3.5\% each, 'Collection development'; 'Bibliometric study'; 'Information Technology' chosen by $2.8 \%$ each and 'Information resources'; 'Quality Management'; 'Public Libraries' with $2.1 \%$ each are the most sought after topics. 
Scenario of the Development of Library and Information Science Schools and Current Research Trends in North India

Table 8 Current Research Topics Registered

\begin{tabular}{|c|c|c|}
\hline Current Research Areas for Ph.D. & No. of topics registered & Percentage \\
\hline User behavior & 14 & 9.9 \\
\hline Web based resources & 8 & 5.6 \\
\hline Information literacy & 7 & 4.9 \\
\hline Digital libraries & 7 & 4.9 \\
\hline Library Services & 6 & 4.2 \\
\hline Cost effectiveness and Cost Benefit Analysis & 5 & 3.5 \\
\hline Electronic resources & 5 & 3.5 \\
\hline Collection development & 4 & 2.8 \\
\hline Bibliometric study & 4 & 2.8 \\
\hline Information Technology & 4 & 2.8 \\
\hline Information resources & 3 & 2.1 \\
\hline Quality Management & 3 & 2.1 \\
\hline Public Libraries & 3 & 2.1 \\
\hline Information Marketing & 2 & 1.4 \\
\hline Online access & 2 & 1.4 \\
\hline Scientometrics & 2 & 1.4 \\
\hline Databases & 2 & 1.4 \\
\hline User Study & 2 & 1.4 \\
\hline Library and information science education & 2 & 1.4 \\
\hline Preservation and conservation & 2 & 1.4 \\
\hline Social Networking & 2 & 1.4 \\
\hline LIS competencies & 2 & 1.4 \\
\hline Consortia & 2 & 1.4 \\
\hline Management & 2 & 1.4 \\
\hline Knowledge Management & 2 & 1.4 \\
\hline Community Information & 2 & 1.4 \\
\hline Human resource development & 2 & 1.4 \\
\hline Library software packages & 2 & 1.4 \\
\hline Library professionals & 2 & 1.4 \\
\hline Resource sharing & 2 & 1.4 \\
\hline Users studies & 2 & 1.4 \\
\hline Stress management & 1 & 0.7 \\
\hline Research productivity & 1 & 0.7 \\
\hline Multimedia resources & 1 & 0.7 \\
\hline E-learning & 1 & 0.7 \\
\hline Information gathering patterns & 1 & 0.7 \\
\hline National library & 1 & 0.7 \\
\hline Retro conversion & 1 & 0.7 \\
\hline Intellectual Property Rights & 1 & 0.7 \\
\hline Information Services & 1 & 0.7 \\
\hline LIS professionals & 1 & 0.7 \\
\hline Cultural properties & 1 & 0.7 \\
\hline Working life of CSIR & 1 & 0.7 \\
\hline Techno stress & 1 & 0.7 \\
\hline Remote sensing & 1 & 0.7 \\
\hline Developing an info gate for visual arts & 1 & 0.7 \\
\hline Job satisfaction & 1 & 0.7 \\
\hline Quality assurance techniques & 1 & 0.7 \\
\hline $\begin{array}{l}\text { Evaluative and critical study of published books in } \\
\text { library and information science }\end{array}$ & 1 & 0.7 \\
\hline Agricultural Information System & 1 & 0.7 \\
\hline Curricula & 1 & 0.7 \\
\hline Faculty members & 1 & 0.7 \\
\hline Citation analysis & 1 & 0.7 \\
\hline
\end{tabular}




\begin{tabular}{|l|c|c|}
\hline Distance Education & 1 & 0.7 \\
\hline University library system. & 1 & 0.7 \\
\hline School libraries & 1 & 0.7 \\
\hline Financial Constraints & 1 & 0.7 \\
\hline Thesaurus & 1 & 0.7 \\
\hline Modeling the information system & 1 & 0.7 \\
\hline Internet surfing & 1 & 0.7 \\
\hline Application of ICT & 1 & 0.7 \\
\hline Radio frequency identification technology & 1 & 0.7 \\
\hline Information management & 1 & 0.7 \\
\hline Networking of libraries & 1 & 0.7 \\
\hline Total & 142 & 100.0 \\
\hline
\end{tabular}

Thus, it is evident from the above Table that users behavior, Web based resources, Information literacy, Digital libraries, Library Services, Cost effectiveness and Cost Benefit Analysis, Electronic resources, Collection development, Bibliometric study, Information Technology, Information resources, Quality Management, Public Libraries are the most sought topics chosen by researchers in LIS Schools. Very few researchers had opted for other topics.

\section{SUGGESTIONS}

The suggestions of LIS School heads, faculties and students were collected through personal visit at Universities and institutes established at North India. On the basis of these the following suggestions and observations have been incorporated.

- Lack of proper infrastructural facilities for teaching such as class rooms, Faculty room and library etc. Lack of Information Technology infrastructure in LIS schools therefore virtually zero exposure to this dynamic new subject.

- Intake of poor quality students due to lack of quality procedures such as merit and entrance test in admission policy; LIS Schools are facing severe paucity of requisitely skilled manpower capable of teaching these courses in comparison to the traditional courses.

- Curriculum not upgraded to current trends in a job oriented market. Changes in LIS curriculum very slow as compared to changes in LIS education because department curricula was not revised nor updated regularly.

- Absence of an accreditation agency in India for quality control and standardization of LIS courses. Western countries like USA and UK have accreditation agencies to monitor and constantly evaluate LIS education.

- Library and Information science syllabi had no uniformity at the national level.

- Lack of adequate teaching and non-teaching staff; Conservative mentality of staff creates problems in team work;

- There is a wide gap between theory and practical papers with most of the time being devoted to teaching theory rather than practical papers; Most of LIS Schools teach only theoretical aspects of LIS education through distance as well as regular courses.

- Commercialization of LIS education is a recent debilitating trend where emerging private universities were organizing the entire course on the basis of single teaching staff at the BLIS and MLIS level. These institutions had scant infrastructure, no computer labs or even libraries facilities. The only purpose of the course is pure commercialization to earn revenue and obtain degrees. The students passing quality are evidence of the poor outputs of these institutions.

- Students unfamiliar with global developments and impact of digital environment on LIS education.

- Part-time contractual staff appointed on fixed meager salaries (about Rs. 7000/- per month) particularly in Uttar Pradesh while most regular posts remain vacant. 
- Knowledge management and Information Communication Technology essential in LIS education but in North Indian universities it is not major part of curriculum.

- Total lack of awareness about LIS subject among students and general public due to traditional work culture in libraries and LIS teaching.

- Lack of coordination between university library and library schools/departments is due to lack of funds, a scientific temper and lack of research culture.

- Students face problems at national and international level examinations like the UGC NET examinations and the entrance exams for Ph. D courses, M. Phil, M. Lib \& I. Sc. courses in other universities due to no uniform curriculum standard.

- Stagnation and saturation had set in the areas of classification cataloguing, Information Technology, management and traditional almost archaic teaching methods.

- Insufficient preparation by faculty for teaching and lack of quality books in LIS education.

\section{CONCLUSIONS}

Administration staff does not understand properly the requirements of LIS department and they are not supportive most of the time as they deny genuine requirements of the LIS department. In other side senior management not provides adequate funds for the development of LIS Schools, So most of the LIS Schools facing the problems of resource crunch. Self-financed departments have very limited budgets as they have to meet the salary of the teaching staff as well as the classroom infrastructure. LIS Schools have lack of modern infrastructure like smart class rooms, separate seminar hall and more PCs due to non budgetary support. Tremendous shortage of teaching and support staff along with lack of computers, teaching equipment, collections, seminar hall, digitization room etc. due to procedural difficulties it is difficult to take adequate initiative. Being at a formative stage, the LIS Department should be developed in its own building to mitigate losses incurred due to constant shifting process. Language as English medium finds problem among students as most of the students are Hindi speaking in the Northern part of India. So they can't interact properly in English. Lack of communication skills at the BLIS level, lack of practical exposes, weak base of students at the MLIS level and M. Phil students are not regularly attending the classes as some of them are engaged in jobs so they skip the classes and create discipline problems at the M. Phil Level.

\section{REFERENCES}

[1] Alimohammadi, D. (2007). Renaming the librarianship in an age of cyber. In Malik, S. and Swain, N. K. (Eds), Librarian to Cybrarian: A Transformational Approach to Librarianship, in press.

[2] Ameen, K. (2007). Issues of Quality Assurance in LIS Higher Education in Pakistan. World Library and Information Congress: $73^{\text {rd }}$ IFLA General Conference and Council, 1923 August 2007, Durban, South Africa. Retrieved from http://www.ifla.org/IV/ifla73/index.htm

[3] Chakravorty, N. C. (1962). Library movement in India: an introductory essay. Delhi: Hindustan Publishing, pp. 1-3.

[4] Konnur, M. B. (1986). Transnational library relations. The Indo-American experience. Unpublished Ph.D. Thesis. University of Pune.

[5] Mahapatra, G. (2006). LIS education in India: Emerging Paradigms, challenges and propositions in the digital era. Asia-Pacific Conference on Library \& Information Education \& practice (pp. 1-5). Singapore. 
[6] Sarkhel, J. K. (2006). Quality assurance and accreditation of LIS education in Indian Universities: Issues and perspectives. In Khoo, C., Singh, D. \& Choudhary, A.S. (Eds.). Proceedings of the Asia-Pacific Conference on Library \& Information Education \& Practice. Singapore: School of Communication \& Information, Nanyang Technological University.

[7] Shrivastava, B. P. (2002). Library and Information science education in Indian Universities. New Delhi: Commonwealth Publishers.

[8] Singh, J. (2014). Standardization, systematic reform and growth of LIS departments in NorthernIndian Universities: a survey. Indian Streams Research Journals, 4(10), pp. 1-13.

[9] Singh, J. (2015). Design and development of model library and information science curricula to Meet the manpower needs of emerging digital era. Thesis submitted to the University of Jammu, Department of Library and Information Science, pp. 340-436.

[10] Varalakshmi, R. S. R. (2009). Curriculum for digital libraries: An analytical study of Indian LIS curricula. D-Lib Magzines, 15 (9/10), p. 1. 